\title{
Determination of Levels of Some Heavy Metals in Fish and Hens Eggs in Sudan
}

\author{
Mawia Hassan Elsaim ${ }^{1,2, ~}$, Aisha Abd Elrhman ${ }^{1}$, Alaa Ali ${ }^{1}$, Rash Jame ${ }^{3}$ \\ ${ }^{1}$ Department of Chemistry, Faculty of Science and Technology, Abdulatif Alhamed University of Technology, Merowe, Sudan \\ ${ }^{2}$ Department of Chemistry, College of Science, Beijing University of Chemical Technology, Beijing, China \\ ${ }^{3}$ Department of Chemistry, Faculty of Education, University of Dalanj, Dalanj, Sudan
}

Email address:

Maelsaimhu7@gmail.com (M. H. Elsaim), maelsaimhu@yahoo.com (M. H. Elsaim)

*Corresponding author

\section{To cite this article:}

Mawia Hassan Elsaim, Aisha Abd Elrhman, Alaa Ali, Rash Jame. Determination of Levels of Some Heavy Metals in Fish and Hens Eggs in Sudan. American Journal of Physical Chemistry. Vol. 7, No. 2, 2018, pp. 37-44. doi: 10.11648/j.ajpc.20180702.15

Received: July 22, 2018; Accepted: August 28, 2018; Published: September 28, 2018

\begin{abstract}
The concentration of the food stuffs by toxic metals is a threat and their exposure for long time has determinate effects on the health tutus of animals. Hen's eggs and fish are one the main sources of protein but if contaminated by toxic heavy metals will cause a harmful effect on human health. This study aimed to assess the concentration of seven microelements performed by Atomic Absorption Spectrophotometer (AAS). Namely (Cadmium, Cobalt, Copper, Iron, Manganese, Lead, and Zinc) in tow samples of some animal products fresh (fish and hens egg) collected from the district popularly in Merowe-city-North Sudan. Heavy metals in hens eggs and fish samples were analyzed using (AAS) in accordance to standard analytical method data obtained were subjected to statistical analysis (ANOVA). To find out the significant difference of toxic heavy metals in fish sample the obtained results showed the average values $\mathrm{Cd}$ and $\mathrm{Pb}(0.100$ and 0.720 $\mathrm{mg} / \mathrm{kg}$ ) respectively in fish sample were higher than permissible limits $(\mathrm{p}<0.05 \mathrm{mg} / \mathrm{kg})$ set by world health organization (WHO). The analysis of heavy metals in fish indicated among seven heavy metals tested, lead showed the highest concentration compered to levels essential elements followed by $(0.170$ for $\mathrm{Co}, 0.420$ for $\mathrm{Cu}, 1.910$ for $\mathrm{Fe}, 0.145$ for $\mathrm{Mn}$, and $2.685 \mathrm{mg} / \mathrm{kg}$ for $\mathrm{Zn}$ ). Our results also showed that accumulation of heavy metals differed in the hens eggs sample recorded high levels of heavy metals found to $\mathrm{Cd}$ and $\mathrm{Pb}(0.070$ and $0.305 \mathrm{mg} / \mathrm{kg})$ respectively. The mean concentrations of essential elements followed (3.335 for $\mathrm{Zn}, 2.200$ for $\mathrm{Fe}, 0.195$ for $\mathrm{Cu} 0.090$ for $\mathrm{Co}$, and $0.070 \mathrm{mg} / \mathrm{kg}$ for $\mathrm{Mn}$ ) respectively. Concentrations in sample of the studied fish showed that there were highly significant different between the $\mathrm{Cd}$ and $\mathrm{Pb}(0.100$ and $0.720 \mathrm{~m} / \mathrm{kg}$ ) than hens eggs $(0.070$ and $0.305 \mathrm{mg} / \mathrm{kg})$.
\end{abstract}

Keywords: Fish, Micro Elements, Hens Eggs, AAS, Heavy Metals, Food Safety

\section{Introduction}

The heavy metals are potentially toxic source and the elements included in this category are $\mathrm{Pb}, \mathrm{Cd}$, As, and $\mathrm{Hg}$. Those elements which have specific greater than five are called heavy metals. Other mineral elements which are nutritionally important and also fit this category include cobalt, iron, copper, manganese, vanadium, molybdenum chromium and zinc [1]. Heavy metals resulting from human activities are the sources of pollution and are continuously released into aquatic and terrestrial ecosystems. Heavy metals contamination is a serious threat because of their toxicity, bio-magnification and bio accumulations in food chain [2]. These contaminants often have direct physiological toxic effects as they are stored or accumulated in tissue as, sometimes permanently [3,4]. The deficiency of elements leads to impairment vital biological process but when they are present in excess, they become toxic such as cadmium exposure causes bone and kidney damage. It has also been identified as potential human carcinogen causing lung cancer $\mathrm{Pb}$ exposures have development and neurobehavioral effects on fetuses, infants and children, elevate blood pressure in adults. Most elements enter the body through diet. Poultry meat and egg have always been sources of protein for human 
and their consumption have increased recently [5]. In children a approximately $4 \%$ uptake of lead is from egg [6]. Found the concentration of $\mathrm{Pb} 0.59 \mathrm{mg} / \mathrm{kg}$ in china while [7] found $\mathrm{Cd} 0.07 \mathrm{mg} / \mathrm{kg}$ egg and $\mathrm{Cu} 0.78 \mathrm{mg} / \mathrm{kg}$ egg in Australian foods. During recent years the presence of toxic heavy metals in foods of animal's origin has got great importance. Mostly we ingest heavy metals such as $\mathrm{Pb}, \mathrm{Cd}$, $\mathrm{Cu}, \mathrm{Co}, \mathrm{Zn}$, and $\mathrm{Fe}$ through food in our daily diet although their levels vary from place to place depending on dietary habits, level of environmental pollution and recycling of poultry food. The above lines indicate the sensitivity of hazard being posed to general public health. This problem requires immediate attention of the health regulatory authorities and the researchers as well. There is serious need of local database or risk assessment studies in local animals and foodstuffs 'to evaluate the potential risk or threat to human s from heavy metals because the Asian countries have different environmental and topographical conditions under which a large number livestock and poultry are growing. The information regarding diseases, health and management of poultry are usually acquired from the literature of western where the nutritional and environmental conditions are different from the Asian countries. Therefore the present study was designed to evaluate the levels of selected heavy metals $(\mathrm{Cd}, \mathrm{Co}, \mathrm{Cu}, \mathrm{Fe}, \mathrm{Mn}, \mathrm{Pb}$, and $\mathrm{Zn})$ in poultry egg and fish in Merowe City to safeguard the local public health. This study will be useful in determining the potential risk from the toxic effects of heavy metals and to make recommendations future implementations by the local health regulatory authorities. River water supports many life form's, provides recreation and fishing to the communities, and it may also be used for drinking purposes and irrigation. However, contamination of river water system by trace metals is of major concern and their determination has received great attention for monitoring environmental pollution since the events of $\mathrm{Hg}$ and $\mathrm{Cd}$ poisoning through fish in Mina Mata, Japan $[8,9]$. The pollution of aquatic environment with heavy metal has been worldwide problem during the recent years because they are indestructible and most of them have toxic effect to organism [10]. Among environmental pollutants, metals are of particular concern due to their toxic effect and ability to bioaccumulation in aquatic ecosystem [11]. Metals tend to accumulate in water and move up through the food chain, therefore, studies to quantify the level of heavy metals in environment and determine potentially hazardous levels for human are necessary [12]. The term heavy metal is applied to the metals and metalloids with atomic density greater than $4 \mathrm{~g} / \mathrm{cm}^{3}$ or 5 time than that of water, they are also known as trace elements because they occur in minute concentration in biological systems [13]. Heavy metals with high relative atomic weight are toxic at low concentration, they do not degrade or do not destroyed or generally they do not break down into less harmful constituents, but accumulate where they are released [14]. Pollution of the aquatic environment by in organic chemical and heavy metals is a major threat to human health and to aquatic organisms [15]. They enter to the aquatic systems from different natural and human activities sources, including industrial or domestic waste water, application of pesticides and in organic fertilizers, leaching from landfills, shipping and harbor activities and atmospheric deposits and geological weathering of the earth crust [16]. Heavy metals can be in corporate in to food chains and absorbed by aquatic organisms to a level that might affects physiological state. They are effective pollutants which have drastic environmental impact on all organisms [17]. Some heavy metals such as $\mathrm{Fe}, \mathrm{Mn}, \mathrm{Co}, \mathrm{Cu}$, and $\mathrm{Zn}$ essential micronutrients for aquatic fauna and flora, but they may be dangerous at high levels [18]. Whereas cadmium and lead are non-essential metals, as they are toxic even in trace amounts [19]. Bio accumulation of heavy metals is capable of leading to toxic level on fish even when the exposure is low and the presence of heavy metals pollution in freshwater environment is known to disturb the normal balance of the aquatic organism. A Fish are notorious for their ability to concentrated heavy metals in their muscles and thus play an important role in humans nutrition, they need to be carefully screened to ensure that un necessary high level of some toxic trace metals are not being transferred to human through fish consumption [20]. Anthropogenic activities continuously increase the amount of heavy metal in the environment, especially in aquatic ecosystem. pollution of heavy metals in aquatic system is growing at an alarming rate and has become an important worldwide problem [21]. Increasing population, urbanization, industrialization and agriculture practices have further aggravated the situation [22]. As heavy metals cannot be degraded, they are deposited, assimilated or incorporated in water, sediment and aquatic animals and thus, causing heavy metals pollution in water bodies, therefore, heavy metals can be bio accumulated and biomagnified via the food chain and finally assimilated by human consumers resulting in health associated risks. As a consequence, fish are often used as indicators of heavy, metals contamination in the aquatic ecosystem because they occupy high tropic levels and are important food source [23]. Fish are considered as one of the most indicative factors, in fresh water ecosystems, for the estimation of trace metals pollution. Heavy metals like copper, iron and zinc are essential for fish metabolism, while some others such as mercury, cadmium and lead have no known role in biological systems, for normal metabolism, the essential metals must be taken up from water or food, but excessive intake of the essential metals can produce toxic effects [24]. Sudan is endowed with diversified surface and underground water resources, and arable lands that are suitable to support vigorous capture fishery activities which centered on the Nile River and its tributaries, and the territorial water of the Red Sea [25]. Fish are often at the top of the aquatic food chain and many concentrate large amount of heavy metals [26] fish is a good source of protein and contains omega 3 -fatty acids that help to reduce the risk of certain cancers [27, 28] and cardiovascular disease [29]. Fish consumption is a major route of trace metal exposure for human [30], and children are more at risk because of their greater intestinal absorptions [31] fish sample can be 
considered as the most significant indicators in fresh water system for estimation of metals pollution level [32]. The aim of the present studied is to assess the concentrations of some microelements in fresh (fish and hens Eggs), and study of the polluted factors has available. Determination of levels of some microelements ( $\mathrm{Cd}, \mathrm{Co}, \mathrm{Cu}, \mathrm{Fe}, \mathrm{Mn}, \mathrm{Pb}$ and $\mathrm{Zn}$ ) in different some a animal's products and to identify public citizens with health risk of such contamination and awareness the conformity of such products with SSMO specifications. To assess the effect of such contaminations on food safety. Determine the factors which effect in the quality of products (Fish and hens Eggs). This study was designed to the levels of some heavy metals in various commercially available brands of products which sold in Sudan markets by using atomic absorption spectrometry and comparing the results with the existing standards for allowable amount set by WHO.

\section{Materials and Method}

\subsection{Sample Collection and Preparation}

Fresh hens eggs sample was collected commercially available from the district popularly in Merowe city-Sudan and fresh fish collect from Merowe Dam on the River Nile, North Sudan.

Tow samples of different animals products Fresh (fish and hens Eggs) were taken and labeled for further determination concentrations of some microelements (cadmium, cobalt, copper, manganese, iron, lead and zinc).

$10 \mathrm{gm}$ from each products was taken into small beaker the beaker was placed in muffle furnace and dried shed at $550 \mathrm{C}^{\circ}$ for 5 hour then cooled. $10 \mathrm{ml}$ of concentrated $\mathrm{HCl}(20 \%)$ was added to the obtained ash and dissolved in $10 \mathrm{ml}$ of demonized water and the solution was filtered in $50 \mathrm{ml}$ conical flask using filter paper, the digested sample was quantitatively into $50 \mathrm{ml}$ volumetric flask and then the volume was completed $50 \mathrm{ml}$ with distilled water

\subsection{Determination of Concentrations in Samples}

The determine of some microelements concentration of samples after treatment the through different condition was used Atomic Absorption Spectrometry (AAS).

\subsection{Data Analysis}

Data collected ware subjected to one-way analysis of variance (AVNOVA) and Duncan multiple Range Test. to determine the difference between heavy metals means at significance rate of $p<0.05$. The standard deviation of heavy metals means was also estimated. All statistics was carrying out using Statistical Analysis program (SPSS, 17)

\section{Results and Discussion}

Heavy metals contents varies widely due to many factors such differences between species, characteristic of manufacturing practices possible contamination coming from equipment's during the process [46]. The results of analyses of seven studied microelements are shown in table (1) the highest concentrations of microelement were detected in the case of zinc $(3.335$ and $2.685, \mathrm{mg} / \mathrm{kg})$, in hens egg than fresh fish. $\mathrm{Cd}, \mathrm{Co}$, and $\mathrm{Mn}$ in the hen's egg sample were detected in very low than permissible limit WHO compared to other metals. Copper $(0.420$ and0.195, $\mathrm{mg} / \mathrm{kg})$. Iron $(1.910$ and $2.200, \mathrm{mg} / \mathrm{kg})$, lead $(0.720$ and $0.305, \mathrm{mg} / \mathrm{kg})$, respectively.

Table 1. The obtained concentrations ( $\mathrm{mg} / \mathrm{kg}$ ) of some metals in some animal products in (10g in $50 \mathrm{ml})$.

\begin{tabular}{llllllll}
\hline Sample label & Cd & Co & Cu & Fe & Mn & Pb & Zn \\
\hline Fish & 0.10 & 0.170 & 0.420 & 1.910 & 0.145 & 0.720 & 2.685 \\
Hens egg & 0.07 & 0.090 & 0.195 & 2.200 & 0.070 & 0.305 & 3.335 \\
\hline
\end{tabular}

Means in the same raw superscript are significant differences at level $(\mathrm{p}<0.05)$

Table 2. Standard Atomic Absorption Condition For element.

\begin{tabular}{|c|c|c|c|c|c|c|}
\hline Element & Wavelength (nm) & Slit (nm) & Relative Noise & Characteristic (mg/l) & Characteristic Check (mg/l) & Linear Range(mg/l) \\
\hline $\mathrm{Cd}$ & 228.8 & 0.7 & 1.0 & 0.028 & 1.5 & 2.0 \\
\hline $\mathrm{Co}$ & 240.7 & 0.2 & 1.0 & 0.012 & 7.0 & 3.5 \\
\hline $\mathrm{Cu}$ & 324.8 & 0.7 & 1.0 & 0.077 & 4.0 & 3.0 \\
\hline $\mathrm{Fe}$ & 248.3 & 0.2 & 1.0 & 0.11 & 6.0 & 6.0 \\
\hline $\mathrm{Mn}$ & 279 & 0.2 & 1.0 & 0.052 & 2.5 & 2.0 \\
\hline $\mathrm{Pb}$ & 283.3 & 0.7 & 0.43 & 0.45 & 20.0 & 20.0 \\
\hline $\mathrm{Zn}$ & 213.9 & 0.7 & 1.0 & 0.018 & 1.0 & 1.0 \\
\hline
\end{tabular}

\subsection{Cadmium Concentration}

The concentration of $\mathrm{Cd}$ in the different animal products samples are $(0.100$ and $0.070, \mathrm{mg} / \mathrm{kg})$ in fish and hens eggs. The cadmium concentration in tow products samples analyzed was lower than allowed limit $(0.5 \mathrm{mg} / \mathrm{kg})$ the recorded by $[33,34]$. Thus could be as result of low pollution to this metal in the study. Regular absorption of cadmium causes damage to the proximal renal tubules and calcium phosphorus, glucose, amino acid and small peptides are loss in the urine. Once calcium accumulates in tissues it cannot be removed safely by chelation therapy without causing kidney damage [44]. Cadmium affects calcium metabolism and skeletal changes resulting from calcium loss and ends in a decrease bone mineral density. 


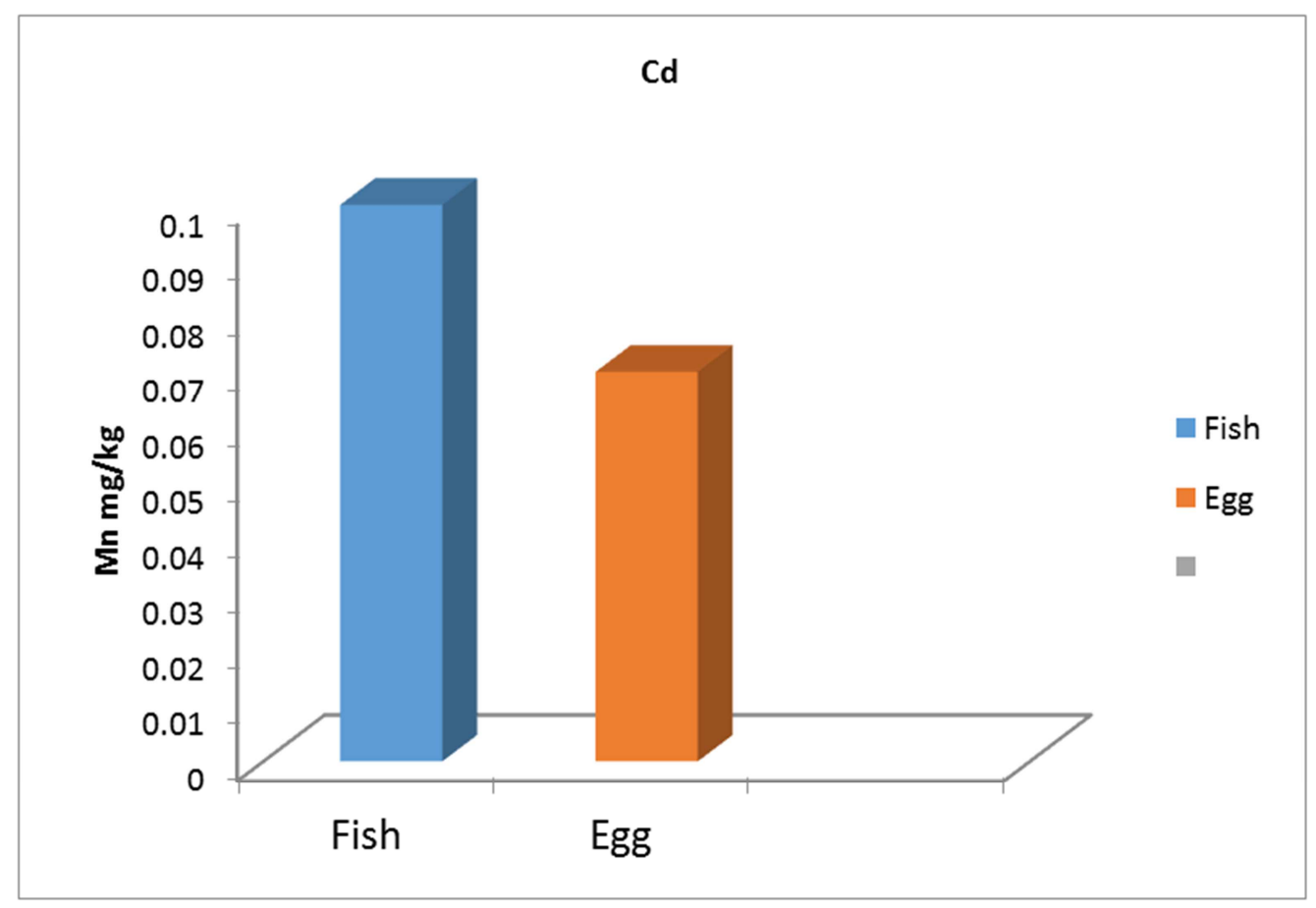

Figure 1. Cadmium Concentration of Some animal products.

\subsection{Cobalt Concentration}

The concentration of cobalt in all samples was presented $(0.170$ and $0.090 \mathrm{mg} / \mathrm{kg})$ respectively no significance difference hens eggs values recorded was observed. However was higher in fresh fish was the concentration of cobalt in fish sample in present study was higher than reported by (U.S. Food and Nutrition Board [35]. Cobalt is a key mineral in the large vitamin B12 the presence of cobalt above the established limit suggests that there are toxicological risks. Cobalt compounds can be carcinogenic if available in ionic from [36].

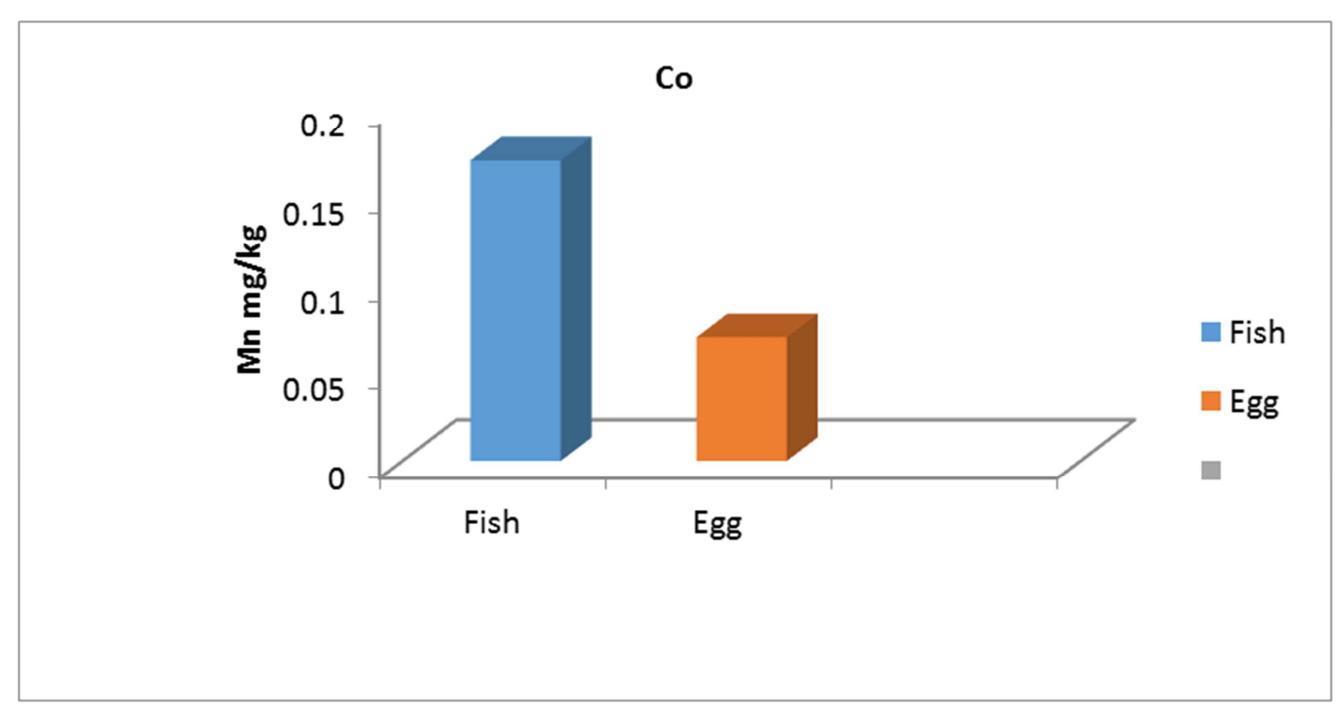

Figure 2. Cobalt concentration ( $\mathrm{mg} / \mathrm{kg}$ ) of some animal's product.

\subsection{Copper Concentration}

The concentration of $\mathrm{Cu}$ in the samples products there was found statistical difference between fish and hens eggs concentrations of $\mathrm{Cu}(0.420$ and $0.195 \mathrm{mg} / \mathrm{kg})$ were observed for fish contained the highest level of $\mathrm{Cu}$ these are below recommended dietary value of (1.5 $-3.0 \mathrm{mg} / \mathrm{day})$, stipulated by [37]. However, the WHO limit for copper is $24.2 \mathrm{mg} / \mathrm{kg}$

This indicates that a animals of this study city is poor source of copper. On the other hand copper is essential trace element that plays a vital role in the physiology of animal for fetal growth and early post-natal development. Excess copper in the body leads to Wilson's disease which characterized by deficient of ceruplasmin [38]. 


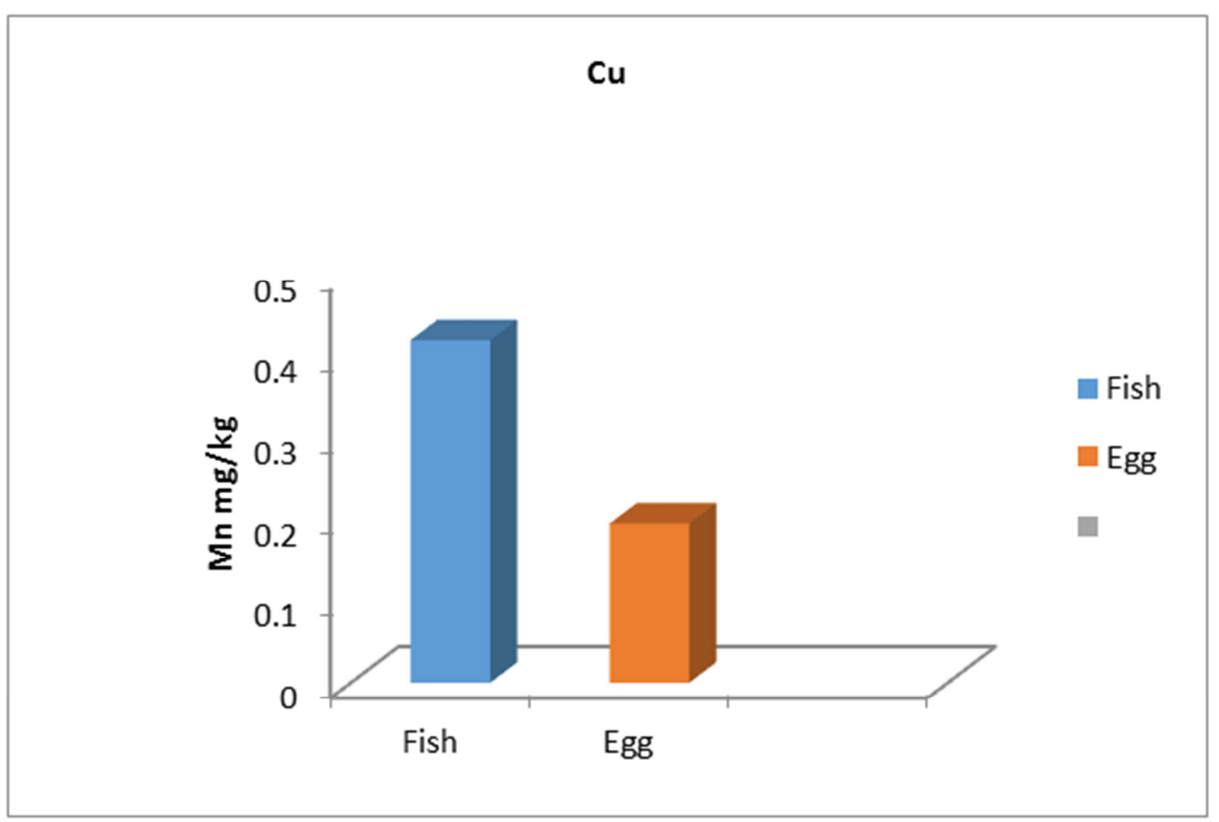

Figure 3. Copper Concentration ( $\mathrm{mg} / \mathrm{kg}$ ) of Some Animal products.

\subsection{Iron Concentration}

The concentration of $\mathrm{Fe}$ in tow samples products the highest Fe concentration were noticed in hens eggs sample (2.200 $\mathrm{mg} / \mathrm{kg}$ ) while the lowest $(1.910 \mathrm{mg} / \mathrm{kg})$ was found in fish, the concentration in all samples hens egg $>$ fish. The permissible limits of World Health Organization (WHO limits for iron is (44.mg/kg) in chicken eggs [39] .

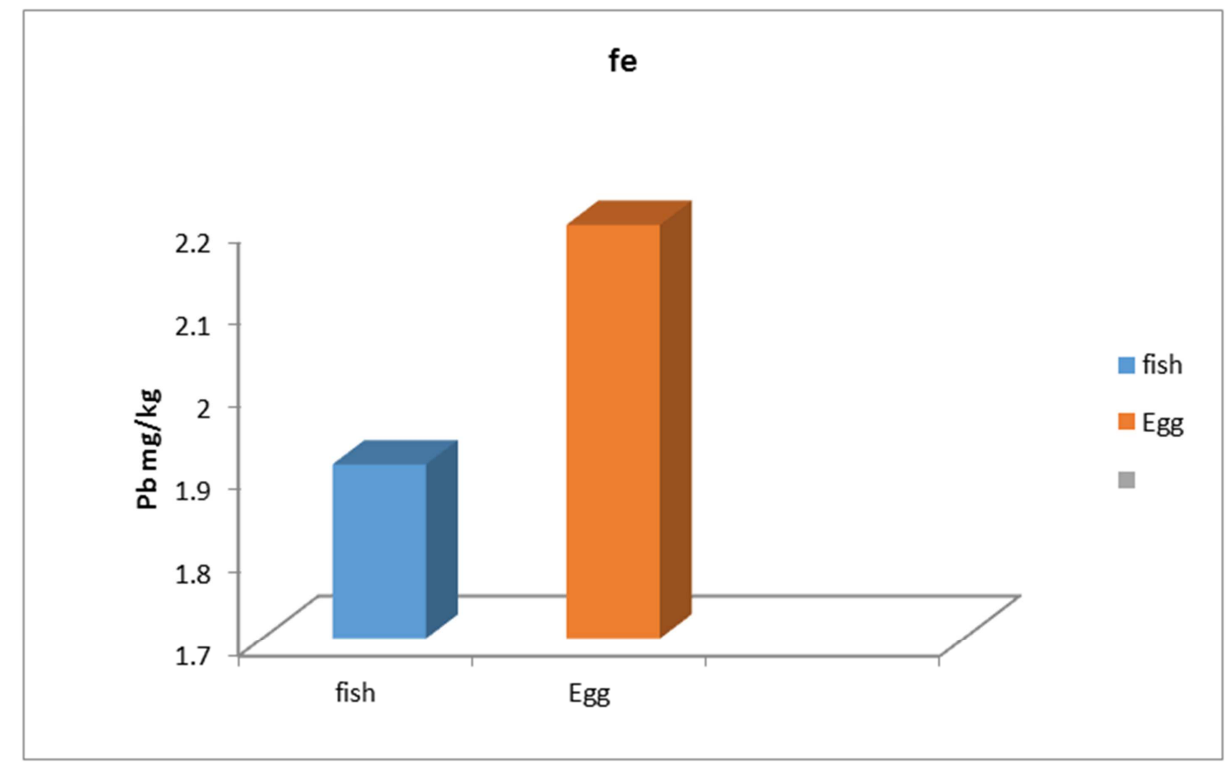

Figure 4. Iron Concentration ( $\mathrm{mg} / \mathrm{kg}$ ) of some Animal products.

\subsection{Manganese Concentration}

The concentration of manganese in tow samples product (fish and hens eggs) is given in figure (5). Highest manganese concentration was noticed in products fish (1.145, $\mathrm{mg} / \mathrm{kg})$ and lowest is found in hens eggs $(0.070, \mathrm{mg} / \mathrm{kg})$. Manganese level in all samples were recorded lower than that limit WHO. Lower limit of latest safe and adequate daily dietary intakes of manganese $(2.3 \mathrm{mg}$ for men and $1.8 \mathrm{mg}$ for women). A common source responsible for increased manganese levels in animal products fodder, particularly whole grain fodder [40]. Mn toxicity can occur individuals with liver failure characterized by manganese accumulation with in the liver other organs such as the brain, the latter results in neurological abnormalities [41]. 


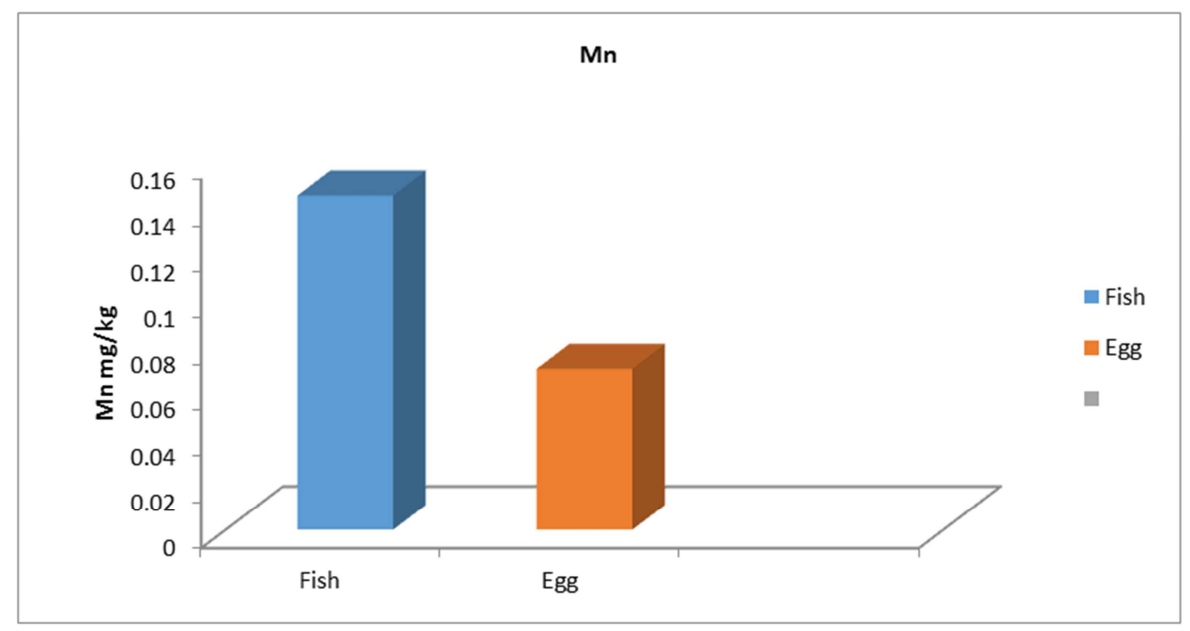

Figure 5. Manganese Concentration ( $\mathrm{mg} / \mathrm{kg}$ ) of Some Animal Products.

\subsection{Lead Concentration}

The concentration of $\mathrm{Pb}$ in samples product were present concentrations $(0.720,0.305, \mathrm{mg} / \mathrm{kg})$ there was significant difference $(p<0.5)$ between the values obtained in different collection sites which is above the recommended dietary allowance for adult study is $(0.720, \mathrm{mg} / \mathrm{kg})$ in fresh fish However $(0.305 \mathrm{mg} / \mathrm{kg})$ in poultry egg. This could be ascribed to the fact that is cosmopolitan area where a lot human activities were taken part. At the same time, there is a big motor garage situated there, as such there is high concentration of car exhaust which source of lead thereby pollution the fodder chicken and silage and products in return. this significant high amount of lead may be due to contamination by industrial plants located around the area were the animals grazed. Lead has no beneficial biological function and is known to accumulate in the body. Lead exposure can adverse health effects, especially in young children and pregnant women, since lead is neurotoxin that permanently interrupts normal brain development [42, 43].

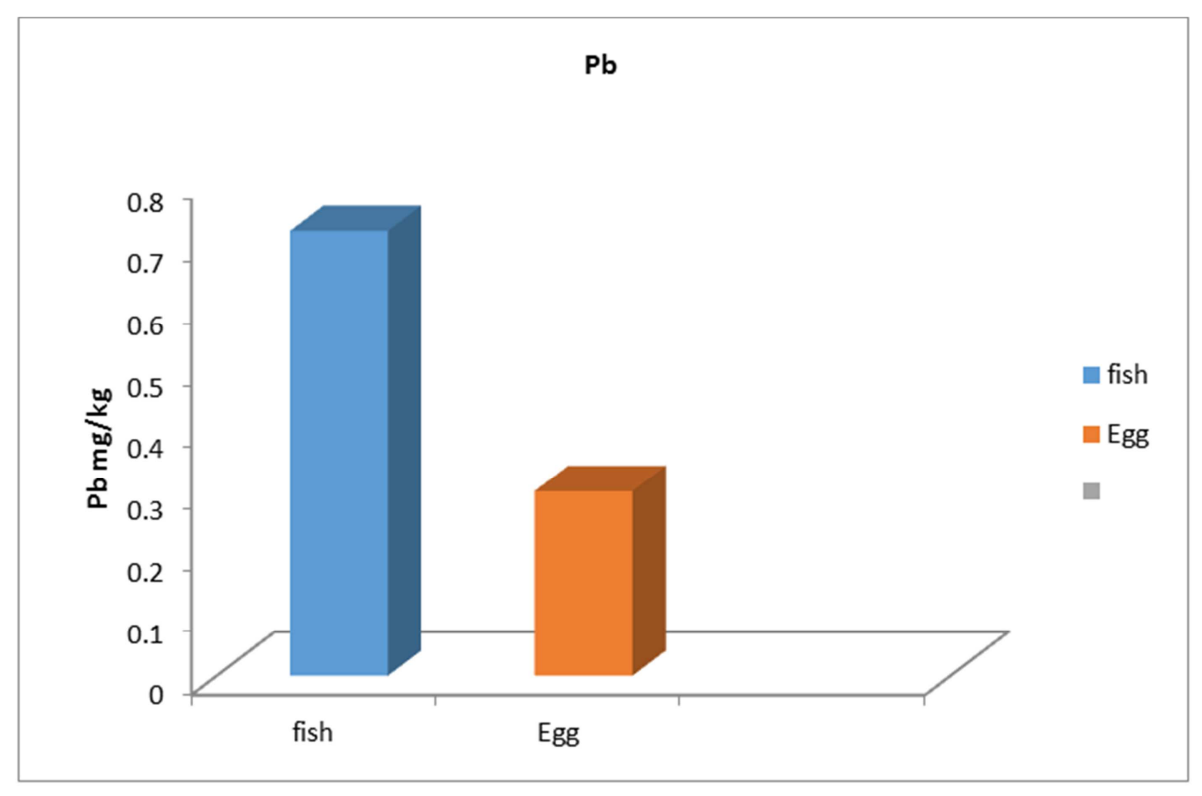

Figure 6. Lead Concentration (mg/kg) of Some Animal Products.

\subsection{Zinc Concentration}

In this study, $\mathrm{Zn}$ is obtained from animal products with concentration were presented in Figure (7) has the lest concentration of $(2.685 \mathrm{mg} / \mathrm{kg})$ in fresh fish and highest concentration of $(3.335, \mathrm{mg} / \mathrm{kg})$ in hens egg. Lower recommended dietary value $(12-15 \mathrm{mg} /$ day) given by [44] Zinc plays an important immune system but excessive absorption of zinc suppresses copper and iron absorption, which results in decrease in erythrocyte. Zinc has numerous functions in the body and it is essential element for human health. At the same time zinc function as a cofactor for many enzymes of the bod. Excess intake of zinc in to the body through food, water or dietary supplements can affect health if large doses of zinc by mouth even for a short time, 
stomach cramps, nausea and vomiting may occur. Ingesting high levels of zinc for several months may cause anemia, damage the pancreas and decrease levels of high -density lipoprotein (HDL) cholesterol [45, 46].

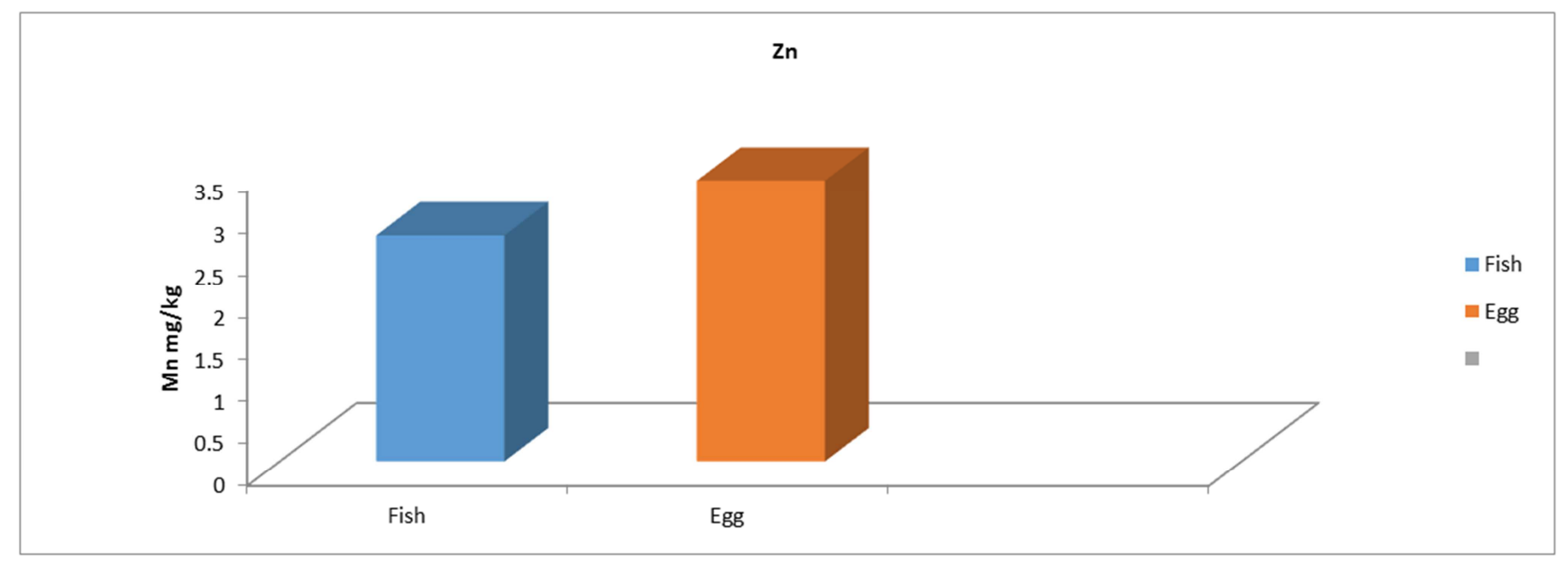

Figure 7. Zinc Concentration ( $\mathrm{mg} / \mathrm{kg}$ ) of Some Animal Products.

\section{Conclusion}

The study was done for concentration of heavy metals cadmium, cobalt, copper, Iron, manganese, Lead and zinc in some animal products fresh( fish and hens eggs) sample consumed in Merowe city north Sudan. Our results indicated that little variability with brand. Generally, $\mathrm{Cd}$, and $\mathrm{Pb}$ concentration in fish exceeded the maximum allowed values stipulated world health organization (WHO) limits $(\mathrm{P}<0.05)$. Whereas the levels of $\mathrm{Cd}$ and $\mathrm{Pb}$ were higher in hens egg. The estimated daily intake values of $\mathrm{Cd}$ and $\mathrm{Pb}$ through hens eggs were found above the recommended permissible levels. The mean concentration of zinc in tow samples has least recommend dietary allowance given as $(12-15 \mathrm{mg} /$ day). The WHO limit for zinc $121 \mathrm{mg} / \mathrm{kg}$. The elevated level could be related to contamination and pollution of the aquatic environment. The estimated daily intake of $\mathrm{Zn}$ was in range of WHO recommended values this indicates that the hen's egg and fish are not adequate source of essential elemental element Zn. Hen's eggs found to be the richest in iron, while fresh fish was found to be the poorest. Among the seven metals in tow samples studied, in fresh fish highest concentration of lead, than hens egg. No significant different observed between $\mathrm{Cd}$ and $\mathrm{Mn}$ in hens eggs. However $\mathrm{Co}$ and $\mathrm{Cu}$ in fish above than eggs sample. Animal products samples for heavy metals in the study work pose a threat of lead and cadmium toxicity due to their exposure to direct sources of air, water and plants.

\section{References}

[1] Hennery, P. R., and R. D. Miles. 2001. Heavy metals Vanadium in poultry. Areview. Ciencia Animal Brasileira Jan. $2(1): 11-26$

[2] Demirezen, O., and K. Uruc. 2006. Comparative study of trace elements in certain fish, meatandmeat products. Foods Chem.

[3] Bokori, J., S. Fekete, R. Glavit, I. Kaday, J. Konez and L.
Kovari. 1996. Complex study of the physiological role of Cadmium IV. Effects of prolonged dietary exposure of broiler chickens to cadmium. ActaVeterinarianHungarica.44:57-74.

[4] Mariam, I., S. Iqbal and S. A. Nigeria 2004. Distribution of some trace and macro minerals in beef, mutt ion and poultry IN. J. Agri. biol.6:816-820.

[5] Madeleine, P., Spiess M., Valceschini E. 2007. Poultry meat consumptiontrendsin Europe. Worlds, Poult. Sci. J. 64.

[6] Hui-fen, Y., L., Xue-Yun and S. Wen 1994 National food contamination monitoring programmers levels of mercury, lead and cadmium in Chinesefood. Biomed Environ. Sci.7: 362-368.

[7] William, C. H., and D. J. David. 1973. The effect of superphosphate on the cadmium content of soil and plants. $\begin{array}{lllll}\text { Aust. J. } & \text { Joil } & \text { Res. } & 11 \text { : } & 43-56\end{array}$ http//dx.doi.org/10.1071/SR9730043.

[8] Mason,: C. F. Biolgy of fresh water pollution, $3^{\text {rd }}$ ed., longman: London., 1996., pp36-377.

[9] Meyer, E. Chemistry of Hazardous Materials, Prentice-hall: Eaglewood Cliffs., 1977., pp 205-207.

[10] Mac Farlane, G. R. and Burchette, M. D. (200). Cellular Distribution of copper, lead and Zinc in the Mangrove, Aviciennamarina (Forsk) Vierh, Aquat. Bot. 68, 45-59.

[11] Censi, P., Spoto, S., E., Saiano, F., Sprovieri, M. and Mazzola S,(2006) Heavy Metals in Coastal Water System A Cast Study from North WesternGuifofChemosphere, 64:1167-1176.

[12] Haram Hassan Abass Bakhiet, 2015. Determination of heavy Metals in fish and water from White Nile Khartoum city Sudan, Journal of Environment protection and sustainable Development Vol. I, n No. 3, pp. 178181.

[13] Duruibe, J O., Ogwuegbu, M. O. C, and Egwurugw, J. N (2007). Heavy metals pollution and human bio toxic effects, Nigeria.

[14] A. S Hammed, D. I. Alim, E. M. Babiker, and H. Assad 2015. Assessment of Heavy metal pollution in the White Nile River in Sudan, International Journal of Advance Research Vole. 3. No 10, 1270-1275. 
[15] Elagba Haj Ali Mohamed, Abdel-Rahman Osman, 2014 Heavy metals in water, Muscles and Gills of oreochromis Nilotic us Collected from the Sewage-Treated water and the white Nile, Sudan Vol 4, No06.

[16] Joseph Clement Akan, Salwa Mahmoud, Bashir Shettima Yikala, Victor Obama Ogugbuaja, 2012 Bioaccumulation of Some heavy metals in fish Samples from River Benue in Vinikilang Adamawa State, Nigeria American Journal of Analytical Chemistry, Vol 3, pp: 727-736.

[17] Zerabruk Tesfamarium, Yunis M. H. Younis, Suleiman's Elsanousi (2016). Assessment of heavy metals status of sediment andwater in Mainefhi and Toker drinking -water reservoirs of Asmara city Eritrea American Journal of Research Communication, Vol 4(6).

[18] M. Ozturk, G Ozozen, O. Minareci (2009). Determination of heavy metal's in fish, water and sediments of Avsar Dam laken Turkey Iran J. Environ. Health. Sei Eng, Vol 6, No. 2, pp 73-80.

[19] Fouzi. A Mohamed, Fathia. A Khogaaliand Assad H Mohamed, 2016 Detection of the accumulation of heavy metals in oreochromisniloticus Fish flesh collected from three different Sudanese dams, International Journal of fisheries and Aquatic Studies Vol. 4, No, 5, pp: 284-80.

[20] Aeniyi AA, Yusuf KA. Determination of heave metals in fish tissues water and bottom Sediments from Epe and Badagry Lagoons, Lagos, Nigeria Environ. Monitor Assess. 2007; 37:451-458.

[21] Malik N, Biswas AK, Qureshi TA, Korana K, Virha R. Bioaccumulation of heavy metals in fish tissues of freshwater lake Bhopal, Environ, Mani. Assess 2010, 160:267-267.

[22] Gig ere A, Campbell PGC, Hare L, McDonald DG, Rasmussen JB. Influence of lake chemistry and fish age on cadmium, copperand zinc concentrations in various organs of indigenous yellow perch (perca flavescent). Cand. J Fish Aquatic Sei 2004; 61:702-716.

[23] Agah H, Leer makers M, Elkins M, Fatima SMR, Banyans W. Accumulation of trace metals in the muscles and liver tissues of five fish species from the Persian Gulf Environ, Monit Assess. 2009; 157:499-514.

[24] Yousafzai AM. Toxicological effects of Industrial effluents dumped in River Kabul on Mahaseer, Tor putitora at Aman Garh industrial area Nowhere Peshawar, Pakistan Ph.D thesis, Department of Zoology, University of the Punjab New Campus Lahore, Pakistan. 2004.

[25] FAO. The composition of fish. Available from 2004. http:L//www.fao.org/weirdoes /tx5916e/x5916col.htm.ppl-80.

[26] Abdel Raheem HAEI-Basis, etal. level of four heavy metals in Two Fish Species collected from Aldubaseen Area Khartoum State, Sudan. EC Nutrition 6.4 (2017):130-134, relevance of chemical speciation in Metals and their compounds in the environment Marine, E. (Ed.), VCH Publishers: Berlin., 1991., pp67-103.

[27] Terry, P.; WOLK, A.; Vainio, H., Weiderpass, E. Cancer Epidemiology. Biom. Prevent. 2002, 11.

[28] Terry, P. Lichtenstein, P. Feychting, M.; Ahlbom, A.; Wolk, A. Lancet. 2001, 357, 1764.

[29] La Vecchia, C.; Chaatenoud, L., ALtieri, A., Tavari, Nutr.
Metabol. Cradiov. Dis. 2001, 11, 10.

[30] Dougherty, C. P.; Henricks Holtz, S.; Reinert, J. C.; Panyacosit, I.; Axelrad, D. A.; Woodruff, T. J. Environ. Res. $2000,84,170$.

[31] Chance. G. W., Harmsen, E. Can. J. Public Health 1998, 89, S10

[32] M. Ozturk, G Ozozen O. Minareci, E Minareci (2009). Determination of heavy metals in fish. Water and Sediments of Avsar Dam Lakein Turkey Iran. J. Environ. Health. Sci Eng, Vol. 6. No. 2, pp73-80.

[33] Nnadozie, C, U, Birnin -Yauri, U. A., Muhammad C (2014) Assessment of some dairy products sold in Sokoto Metropolis, Nigeria. Inter. J., Adv. Res. in Chem. Sctry 1(10), 31-37.

[34] Nordberg G. F. (2004): Cadmium and health in the 21 centaury -historical remarks atrends for the future Bio Metals. 17(5):485-489.

[35] D.C National Academy Press: 394-419, 2001 Food and Nutrition Board, Institute of Medicine. Manganese Dietary reference intakes for vitamin $\mathrm{A}$, vitamin $\mathrm{K}$ boron, chromium, copper, iodine, iron, manganese, molybdenum, nickel, silicon, vanadium and zinc Washington.

[36] G R E I M H., SNYDER R. Toxicology and Risk Assessment: A.

[37] R. N. C., National Research council, (1989). Recommended dietary allowance, National Academy press Washington DC, Pp. 36-39.

[38] Lawal, A. O., Mohammed, S. S., Damisa, D., 2006, Assessment of levels of copper, cadmium and lead in secretion of mammary gland of Cows grazed on open fields., Sci world J., 1(1), 7-10.

[39] Meshref AMS, Moselhy WA Hassan NE-H (2014) Heavy metals and trace element levels in milk products. food measure 8:381-388. pp.

[40] Zmudzki, J., and Szkoda J. (1996): Concentration of trace element in hens egg in Polar Bromatologa-i-ChemaToksyologiczna. 29:55-57. P.

[41] G ROPPET S, S., SMITH J. L, GROFF J. L., Advanced Nutrition and Human M etabolism. Thomson Wadsworth, $4^{\text {th }}$ Ed. Chapter 12, 2005.

[42] HAUSERR. A., ZESIEWICZT. AROSEMURGY A, S., MARTINEZ C OLANOWC. W. Manganese intoxication and chronicliverfailure. Ann. Neurol., 36871, 1994.

[43] ATSDR (2011), Agency for Toxic Substance and Disease Registry. lead toxicity: How Are People Exposed lead ? Achieved Prom, the, original.

[44] SSMO (2008a) and (2008b). Sudanese standard and metrolog Organization. Concentrations in milk SDS, 3952/2008. And concentrations in meat and meat products, SDS4144/2008.

[45] Tassew, B. Ahmed, H. and Vegi Maheswara, R. (2014). Determination of concentration of Selected H heavy Metal s in cow's milk: Borena Zone, Ethiopia. Journal of Health Science, 4(5):105-112.

[46] Yuzbasi, N., Sezgin, E Yildrim, M. and Yildirim, N. (2003). Survey of lead, cadmium, iron and copper and zinc in kasar. food chemistry 20(5): 464-469. Comprehensive Introduction. John Wiley \& Sons, Ltd USA, chapter 6m 2008. 